\title{
ANALYSIS OF THE PROPERTIES OF EXPANSIVE CONCRETE WITH PORTLAND AND BLAST FURNACE CEMENT
}

\author{
W. JACKIEWICZ-REK ${ }^{1}$, J. KUZIAK ${ }^{2}$, B. JAWORSKA ${ }^{3}$
}

\begin{abstract}
The properties of expansive concretes made of two types of cement: Portland cement CEM I and blast furnace slag cement CEM III were tested. The expansion of the concrete was caused by using an expansive admixture containing aluminium powder added in an amount of $0.5 ; 1$ and $1.5 \%$ of cement mass. It was found that the compressive strength of concrete with CEM I decreased after using an expansive admixture in the amount of more than $0.5 \%$ of the cement mass. The compressive strength of concrete with CEM III decrease after addition of admixture in the entire range of dosages used. On the basis of electrochemical measurements, it was found no influence of an expansive admixture on corrosion of reinforcing steel. The use of an expansive admixture causes a slight increase in the effective diffusion coefficient of chloride ions in concrete.
\end{abstract}

Keywords: expansive admixture, Portland cement, blast furnace slag cement, concrete, compressive strength, polarization curve of steel, chloride diffusion

\footnotetext{
${ }^{1} \mathrm{PhD}$., Warsaw University of Technology, Faculty of Civil Engineering, Lecha Kaczyńskiego 16, 00-637 Warsaw, Poland, e-mail: w.jackiewicz-rek@il.pw.edu.pl

${ }^{2} \mathrm{PhD}$., Warsaw University of Technology, Faculty of Civil Engineering, Lecha Kaczyńskiego 16, 00-637 Warsaw, Poland, e-mail: j.kuziak@il.pw.edu.pl

${ }^{3} \mathrm{PhD}$., Warsaw University of Technology, Faculty of Civil Engineering, Lecha Kaczyńskiego 16, 00-637 Warsaw, Poland, e-mail: b.jaworska@il.pw.edu.pl
} 


\section{INTRODUCTION}

Concretes made from general-purpose cements are subject to shrinkage during setting and curing. This phenomenon occurs due to physical and chemical processes, mainly concrete drying. It is an adverse process which can lead to cracks. Expansive concretes, among others, were developed to counteract the effects of concrete shrinkage. The hydration of such cements features the formation of compounds that crystallise along with the increase in volume, which is why concretes made from such cements (expansive concretes) are characterised by an increase in volume instead of shrinkage $[4,21]$. Expansive cements, in contrast to "non-expansive" cements, are characterised by increased calcium sulphate content and include the Klein's Compound $\left(\mathrm{C}_{4} \mathrm{~A}_{3} \overline{\mathrm{S}}\right.$ sinter $)$ increased $\mathrm{C}_{3} \mathrm{~A}$ content or calcium aluminate cement. Expansive cement is not featured in the European standardisation documents. On the other hand, the American ASTM C845 [1] standards distinguish three types of expansive cements: 1) $\mathrm{K}$ - including $\mathrm{C}_{4} \mathrm{~A}_{3} \overline{\mathrm{S}}$, calcium sulphate and free calcium oxide, 2) $\mathrm{M}$ - including calcium aluminate cement and calcium sulphate, 3) $\mathrm{S}$ - including $\mathrm{C}_{3} \mathrm{~A}$ and calcium sulphate.

During cement setting, calcium sulphate reacts with aluminates, thereby giving ettringite (1.1), which crystallises along with increase in volume.

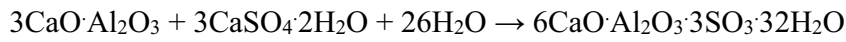

Due to the increased content of calcium sulphate and aluminates $\left(\mathrm{C}_{4} \mathrm{~A}_{3} \overline{\mathrm{S}}, \mathrm{C}_{3} \mathrm{~A}\right.$, aluminates in calcium aluminate cements) in expansive cements, their setting features increased quantity of ettringite which causes an increase in the concrete's volume.

Concrete expansion can also be invoked by using calcium oxide and magnesium oxide. These compounds react with water during cement setting and create respectively portlandite $\left(\mathrm{Ca}(\mathrm{OH})_{2}\right)$ and brucite $\left(\mathrm{Mg}(\mathrm{OH})_{2}\right)$, which are also crystallised along with an increase in volume, thereby resulting in concrete expansion.

A characteristic feature of concretes made from expensive cements or including calcium and magnesium oxides is the increase in volume of hydration products as well as inward expansion. This 
results in the improvement of such concrete features as tightness, frost resistance, mechanical strength and resistance against sulphate aggression, among others [4].

A new approach to expansive concrete is invoking expansion by adding aluminium powder. Hitherto, aluminium powder was used in concrete technology for concrete aeration, lightweight concrete production, autoclaved cellular concrete, among others [7]. In alkaline conditions, aluminium reacts, thereby causing the emission of gaseous hydrogen. This reaction takes place, among others, in concrete which is characterised by an alkaline reaction due to the presence of calcium hydroxide formed in reactions of calcium silicates with water (1.2) during cement setting [5]:

$$
2\left(3 \mathrm{CaO} \cdot \mathrm{SiO}_{2}\right)+6 \mathrm{H}_{2} \mathrm{O} \rightarrow 3 \mathrm{CaO} \cdot 2 \mathrm{SiO}_{2} \cdot 3 \mathrm{H}_{2} \mathrm{O}+\mathrm{Ca}(\mathrm{OH})_{2}
$$

Furthermore, a concrete mix features small quantities of $\mathrm{NaOH}$ and $\mathrm{KOH}$ that increase the mixture's alkalinity. Aluminium reacts with calcium hydroxide present in the concrete mix, thereby creating gaseous hydrogen $(1.3,1.4)[22]$ :

$$
\begin{gathered}
2 \mathrm{Al}+3 \mathrm{Ca}(\mathrm{OH})_{2}+6 \mathrm{H}_{2} \mathrm{O} \rightarrow 3 \mathrm{CaO} \cdot \mathrm{Al}_{2} \mathrm{O}_{3} \cdot 6 \mathrm{H}_{2} \mathrm{O}+3 \mathrm{H}_{2} \\
2 \mathrm{Al}+\mathrm{Ca}(\mathrm{OH})_{2}+6 \mathrm{H}_{2} \mathrm{O} \rightarrow \mathrm{Ca}\left[\mathrm{Al}(\mathrm{OH})_{4}\right]_{2}+3 \mathrm{H}_{2}
\end{gathered}
$$

The volume of the concrete mix is increased due to the pressure exerted by the formed gas. Due to the above fact, aluminium powder can be used for manufacturing expansive concretes in order to effectively fill out hard-to-reach places, such as crevices or cavities and to manufacture concretes with limited shrinkage to prevent cracking.

Concrete expansion depends, among others, on the quantity of aluminium powder, concrete mix temperature and alkali content in the cement [6]. In the case of cements with low alkali content, it is recommended to add sodium or calcium hydroxide in order to ensure an adequate quantity of $\mathrm{OH}-$ ions for reaction with aluminium [6].

The addition of aluminium powder to concrete mix causes an increase in concrete porosity and decrease in its density and strength [8]. 


\section{SUBJECT AND SCOPE OF CONDUCTED RESEARCH}

The conducted research was aimed at determining the impact of an expansive admixture including aluminium on concrete's strength features and protective capabilities for reinforcing steel. The subject of research were concretes made with the use of Portland cement (CEM I) and blast furnace cement (CEM III) which only vary in terms of dosage of the expansive admixture $(0 \% ; 0.5 \% ; 1 \% ; 1.5 \%$ of cement mass).

The scope of the conducted research covered the following: studying the consistency of the concrete mix with the use of the slump test, studying the concrete's compressive strength and the concrete's protective capabilities for reinforcing steel in the scope of corrosion tests of steel in aqueous extracts from concrete and diffusion of chloride ions in concrete. Additionally, the research featured the determination of the concrete volume increment - concrete expansion within up to 1 hour from the time of mixing the concrete mix components.

\subsection{RESEARCH METHODOLOGY}

The designation of the concrete mix consistency was conducted with the use of the slump test according to PN-EN 12350-2:2011 [15]. The concrete's strength testing was conducted on a case-bycase basis on 3 samples with the dimensions of 150x150x150 mm, prepared according to PN-EN 12390-1:2001 [16]. Until the time of testing, the samples were stored in an environmental chamber according to PN-EN 12390-2 [17]. The testing was conducted with the use of the CONTROLS MCC 8 strength testing machine coherent with the PN-EN 12390-4:2001 standard [19]. The compressive strength was designated after 2, 7, 28 and 90 days from moulding in accordance with PN-EN123903:2011 [18].

The testing of the impact of the expansive admixture on the concrete cover's protective properties was conducted with the use of concrete samples with the CEM III cement. The CEM III cement concrete is characterised by lower alkalinity than concrete with CEM I [3]. Expansive admixture that includes aluminium can additionally reduce the concrete's alkalinity due to the use of calcium hydroxide for reaction with aluminium Eq. (1.3), Eq. (1.4). Due to the above, it was necessary to test 
whether the admixture affects the $\mathrm{pH}$ of the concrete cover from CEM III cement and whether it affects its protective properties in relation to reinforcing steel.

The impact of the admixture on the reinforcement's corrosion was determined on the basis of anodic polarisation curves of steel in aqueous extracts from concretes with CEM III cements, with $1 \%$ and $1.5 \%$ of expansive admixture. For comparison, polarisation curves in the aqueous extract from CEM III concrete without expansive admixture were recorded. In order to prepare the aqueous extract from concrete, the concrete was ground and mixed with distilled water with a mass ratio of 1:1. After approx. $20 \mathrm{~h}$ of leaching, a liquid which roughly corresponded to the concrete's porous liquid was filtered. The solutions' $\mathrm{pH}$ was measured with the $781 \mathrm{pH} / \mathrm{Ion}$ Meter Metrohm $\mathrm{pH}$ meter.

The steel polarisation curves were executed on the Autolab PGSTAT 302N kit after $1 \mathrm{~h}$ of exposure in the tested solutions. The measurements were conducted in a three-electrode system. The working electrode was a smooth rod from S235JRG2 steel. The surface of steel rods was cleaned with sandpaper (a gradation of 100 to 220), then degreased with acetone and washed with ethanol. The steel's active surface amounted to $3.4-3.8 \mathrm{~cm}^{2}$. The reference electrode was a saturated calomel electrode. The auxiliary electrode was a metal sheet from steel resistant to corrosion, with the dimensions of $50 \times 95 \mathrm{~mm}$. The starting potential amounted to $-0.1 \mathrm{~V}$ in relation to the corrosion potential $\left(\mathrm{E}_{\mathrm{cor}}\right)$. The rate of potential changes amounted to $1 \mathrm{mV} / \mathrm{s}$. Prior to recording the polarisation curve, a short impedance measurement (frequency range: 1000-0.01 Hz, excitation signal amplitude: $10 \mathrm{mV}$ ) was conducted to designate the solution's resistance and later correct the obtained polarisation curves with the IR drop.

The testing of the impact of the expansive admixture on the diffusion of chloride ions in concrete was also conducted on samples of concrete from CEM III due to its use in engineering structures which are exposed to the effects of de-icing salt which includes chlorides. Chloride ions that penetrate the concrete are a corrosion hazard for concrete's reinforcement steel [2] The testing was conducted after 7 weeks of concrete curing on samples including $1 \%$ of expansive admixture (dose recommended by the manufacturer) and comparative samples without admixture. Samples with the dimensions of 150x150x60 mm (cut out from 150x150x150 mm samples) were used for the tests. Prior to testing, the samples were placed in distilled water for 5 days for water saturation purposes. The saturated samples were placed in a $3 \% \mathrm{NaCl}$ solution for 31 days. After that time, the samples were removed 
from the solution, gently dried with paper towels and the Profile Grinder kit was used to collect concrete samples from various depths for chloride ion designations. The samples were collected on the side of the cutting surface. The thicknesses of the collected concrete layers amounted to $0.8-1$ $\mathrm{mm}$. Chloride ions were determined using the Volhard method. The content of chloride ions in reference concretes (not placed in $\mathrm{NaCl}$ solution) was also determined.

The effective diffusion coefficient $\left(\mathrm{D}_{\text {eff }}\right)$ was designated based on the fitting of the obtained chloride content values to the Eq. (2.1). During the fitting, the content of chlorides in the first (external) concrete layer was not taken into consideration.

$$
c=c_{0}\left(1-\operatorname{erf}\left(\frac{x}{2 \sqrt{D_{\text {eff }}}}\right)\right)
$$

where:

$\mathrm{c}$ - chlorides content in concrete at depth $\mathrm{x}, \mathrm{c}_{0}$ - chlorides content in the near-surface layer of concrete, erf error function, $\mathrm{x}$ - distance from the concrete surface, $\mathrm{t}$ - time of chlorides diffusion in concrete, $\mathrm{D}_{\text {eff }}$ - effective diffusion coefficient.

In order to take into consideration the starting content of chlorides in concrete, calculations for the chloride ions content after correction with the starting content (after deducting the chloride ions content in reference samples not subjected to chloride ions penetration) were also conducted.

\subsection{MATERIALS USED FOR RESEARCH AND THEIR CHARACTERISTICS}

Two types of cements were used in the conducted tests: Portland cement (CEM I 42,5 R) and blast furnace slag cement (CEM III/A 42,5N LH HSR NA) compatible with the standard PN-EN 1971:2012 [10] (Table 1).

Mineral aggregate in the form of sand of the Vistula fraction 0/2 and a coarse aggregate - washed gravel 2/16 in accordance with PN-EN 12620 + A1: 2010 [20] were used to prepare the concrete mix. As a mixing water was used tap water which meets the requirements of PN-EN 1008: 2004 [14]. In addition, a fluidizing admixture compatible with the standard PN-EN 934-2: 2010 [12] was applied 
in order to obtain the assumed consistency of the concrete mix. In order to cause expansion of the concrete, an expansive admixture containing aluminium powder meeting the requirements of PN-EN 934-4 [13] was used. Table 2 presents selected parameters of the admixtures used.

Table 1. Physicochemical parameters of Portland and blast furnace slag cement acc. manufacturers' data

\begin{tabular}{|c|c|c|c|c|}
\hline \multirow{2}{*}{ Parameter } & \multicolumn{2}{|c|}{$\begin{array}{l}\text { Requirements according to the } \\
\text { standard PN-EN 197:2012 }\end{array}$} & \multicolumn{2}{|c|}{ Results of determinations } \\
\hline & CEM I 42,5 R & CEM III/A 42,5 N & CEM I 42,5 R & $\begin{array}{c}\text { CEM III 42,5N } \\
\text { LH HSR NA }\end{array}$ \\
\hline $\begin{array}{l}\text { The beginning of setting } \\
\text { time [min] }\end{array}$ & $\geq 60$ & $\geq 60$ & 184 & 216 \\
\hline End of setting time [min] & - & - & 242 & 292 \\
\hline $\begin{array}{c}\text { Compressive strength } \\
\text { [MPa] } \\
\text { - after } 2 \text { days } \\
\text { - after } 28 \text { days }\end{array}$ & $\begin{array}{c}\geq 20,0 \\
\geq 42,5 \leq 62,5\end{array}$ & $\begin{array}{c}\geq 10,0 \\
\geq 42,5 \leq 62,5\end{array}$ & $\begin{array}{l}30,1 \\
60,2 \\
\end{array}$ & $\begin{array}{l}15,2 \\
58,8 \\
\end{array}$ \\
\hline $\mathrm{SO}_{3}$ content $[\%]$ & $\leq 4,0$ & $\leq 4,0$ & 2,95 & 2,32 \\
\hline $\mathrm{Cl}^{-}$content $[\%]$ & $\leq 0,1$ & $\leq 0,1$ & 0,089 & 0,08 \\
\hline Roasting losses [\%] & $\leq 5,0$ & $\leq 5,0$ & 3,33 & 1,00 \\
\hline Change in volume [mm] & $\leq 10$ & $\leq 10$ & 1 & lack of information \\
\hline
\end{tabular}

Table 2. Properties of the admixtures used

\begin{tabular}{|c|c|c|}
\hline Properties & $\begin{array}{c}\text { Fluidizing } \\
\text { admixture } \\
\text { polycarboxylic } \\
\text { ether }\end{array}$ & $\begin{array}{c}\text { Expansive admixture } \\
\text { aluminium powder, } \\
\text { plasticizer }\end{array}$ \\
\hline Basic component & liquid & powder \\
\hline Form & yellowish & light brown \\
\hline Colour & $\leq 0,1$ & $0,92 \mathrm{~kg} / \mathrm{cm}^{3}$ \\
\hline Density (in $\left.20^{\circ} \mathrm{C}\right)\left[\mathrm{g} / \mathrm{cm}^{3}\right]$ & $1,05 \pm 0,02 \mathrm{~g} / \mathrm{cm}^{3}$ & $\leq 0,1$ \\
\hline Cl- content $[\%]$ & $\leq 1,0$ & - \\
\hline Alkali content $[\%]$ & $\leq 10$ & 1 \\
\hline Change in volume $[\mathrm{mm}]$ & & \\
\hline
\end{tabular}




\subsection{SUBJECT OF TESTING}

8 compositions of concrete with the CEM I 42.5 R Portland cement and CEM III/A 42,5N LH HSR NA blast furnace cement with various expansive admixture contents were designed (Table 3 ). The expansive admixture was mixed with cement. An exception were the samples for testing the increase in height, during which the admixture was added after mixing all other concrete mix components. The water-cement ratio $(\mathrm{w} / \mathrm{c})$ of all concretes amounted to 0.37 . The samples for testing each type of concrete were made from the volume of a single batch which amounted to $85 \mathrm{dm}^{3}$.

Table 3. Composition of designed concretes

\begin{tabular}{|c|c|c|c|c|c|c|c|c|}
\hline \multirow{2}{*}{ Component } & \multicolumn{7}{|c|}{ Composition of $1 \mathrm{~m}^{3}$ of concrete [kg] } \\
\cline { 2 - 9 } & $\begin{array}{c}\text { CEM I } \\
(0 \%)\end{array}$ & $\begin{array}{c}\text { CEM I } \\
(0,5 \%)\end{array}$ & $\begin{array}{c}\text { CEM I } \\
(1 \%)\end{array}$ & $\begin{array}{c}\text { CEM I } \\
(1,5 \%)\end{array}$ & $\begin{array}{c}\text { CEM III } \\
(0 \%)\end{array}$ & $\begin{array}{c}\text { CEM III } \\
(0,5 \%)\end{array}$ & $\begin{array}{c}\text { CEM III } \\
(1 \%)\end{array}$ & $\begin{array}{c}\text { CEM III } \\
(1,5 \%)\end{array}$ \\
\hline Sand 0/2 & 698 & 698 & 698 & 698 & 698 & 698 & 698 & 698 \\
\hline Gravel 2/8 & 524 & 524 & 524 & 524 & 524 & 524 & 524 & 524 \\
\hline Gravel 8/16 & 718 & 718 & 718 & 718 & 718 & 718 & 718 & 718 \\
\hline Cement & 380 & 380 & 380 & 380 & 380 & 380 & 380 & 380 \\
\hline CEM I & CEM I & CEM I & CEM I & CEM III & CEM III & CEM III & CEM III \\
\hline $\begin{array}{c}\text { Fluidizing } \\
\text { admixture }\end{array}$ & 3,6 & 3,6 & 3,6 & 3,6 & 3,6 & 3,6 & 3,6 & 3,6 \\
\hline $\begin{array}{c}\text { Expansive } \\
\text { admixture }\end{array}$ & 0 & 1,8 & 3,6 & 5,4 & 0 & 1,8 & 3,6 & 5,4 \\
\hline
\end{tabular}

\section{Properties OF EXPANSIVE CONCRETES}

\section{Volume expansion}

The increase in volume of concrete mix with expansive admixture in the quantity of $0.5 \%$ of the CEM I cement mass is minor and does not exceed $1 \mathrm{~mm}$ of the sample's height (Table 4). The use of the given expansive admixture in the quantity of $0.5 \%$ of cement's mass is ineffective in obtaining expansive concrete. A substantially better effect was obtained when the dosage amounted to $1 \%$ and 
$1.5 \%$ of cement's mass (Fig. 1). Then, the cubic sample's height increase reached even $15 \mathrm{~mm}$, which in conversion to volume gives approx. 10\% of volume increase (150x150x150 mm sample). The highest increase in volume was recorded in the time of 10 to 20 minutes from the moment of cement and water contact.

Table 4. The results of height increase - expansion of concrete specimens

\begin{tabular}{|c|c|c|c|c|}
\hline & \multicolumn{4}{|c|}{ Increase in height of samples, \% } \\
\hline $\mathrm{t}$, min & 10 & 20 & 30 & 60 \\
\hline CEM I $(0,5 \%)$ & 0,0 & 0,7 & 0,7 & 0,7 \\
\hline CEM I (1\%) & 0,0 & 4,0 & 5,3 & 6,0 \\
\hline CEM I $(1,5 \%)$ & 2,0 & 6,7 & 8,0 & 10 \\
\hline
\end{tabular}

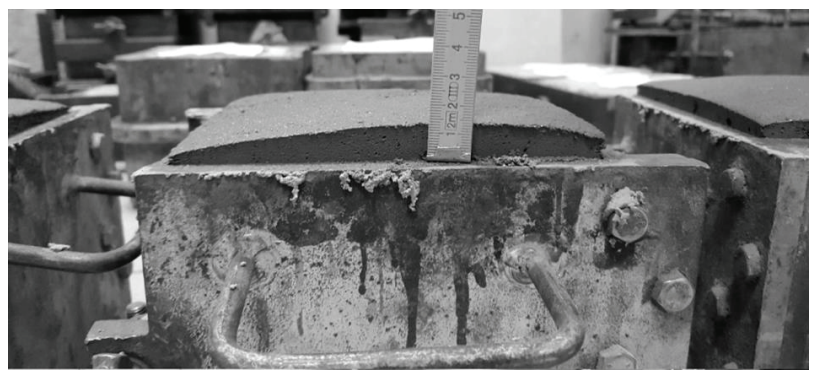

Fig. 1. The expansion of the samples after 60 minutes from contact of cement with water

In the case of concrete with blast furnace cement, the samples' volume increase is also minor.

\section{Consistency}

The consistencies of all concrete mix made with the use of the CEM I Portland cement without admixture and with expansive admixture added in the quantity of 0.5 and $1 \%$ are similar to one another (Table 5) and can be classified as the S3 consistency class according to PN-EN 206:2014-04 [11]. A substantial change in the consistency of the CEM I mixture was observed after increasing the 
quantity of admixture to $1.5 \%$ of cement's mass. In this case, a substantially denser concrete mix corresponding to the S1 consistency class was obtained. In the case of mix with blast furnace cement (CEM III), a clear dependency between consistency and the quantity of used expansive admixture was observed - along with the increased dosage of the expansive admixture, the slump was becoming smaller. Along with the increase in the quantity of admixture, the concrete mix consistency class changed from S4 to the boundary of S2/S1.

Table 5. The results of the measurement of the consistency of a concrete mix using the clone slump method

\begin{tabular}{|c|c|c|}
\hline Concrete mix & $\begin{array}{c}\text { Clone slump } \\
(\mathrm{mm})\end{array}$ & $\begin{array}{c}\text { Consistency } \\
\text { class acc. } \\
\text { PN-EN } \\
\text { 206:2014-04 }\end{array}$ \\
\hline CEM I $(0 \%)$ & 100 & $\mathrm{~S} 3$ \\
\hline CEM I $(0,5 \%)$ & 100 & $\mathrm{~S} 3$ \\
\hline CEM I $(1 \%)$ & 120 & $\mathrm{~S} 3$ \\
\hline CEM I $(1,5 \%)$ & 30 & $\mathrm{~S} 1$ \\
\hline CEM III $(0 \%)$ & 190 & $\mathrm{~S} 4$ \\
\hline CEM III $(0,5 \%)$ & 160 & $\mathrm{~S} 4$ \\
\hline CEM III $(1 \%)$ & 60 & $\mathrm{~S} 2$ \\
\hline CEM III $(1,5 \%)$ & 45 & $\mathrm{~S} 1 / \mathrm{S} 2$ \\
\hline
\end{tabular}

\section{Compressive strength}

Both in the case of concrete with CEM I and CEM III a clear increase in compressive strength up to the $28^{\text {th }}$ day of curing was observed (Fig. 2). After that time, the increase in compressive strength was minor. 
a)

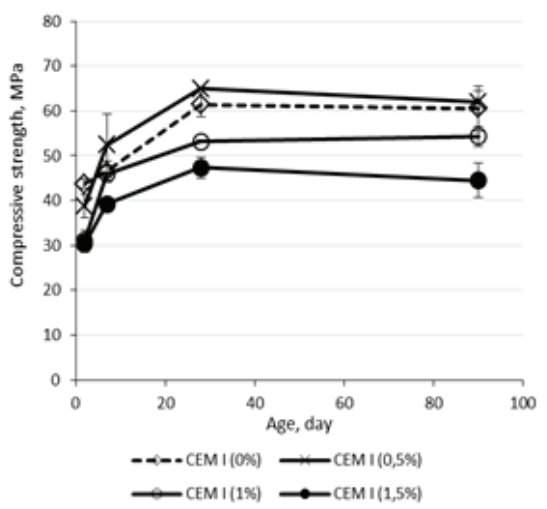

b)

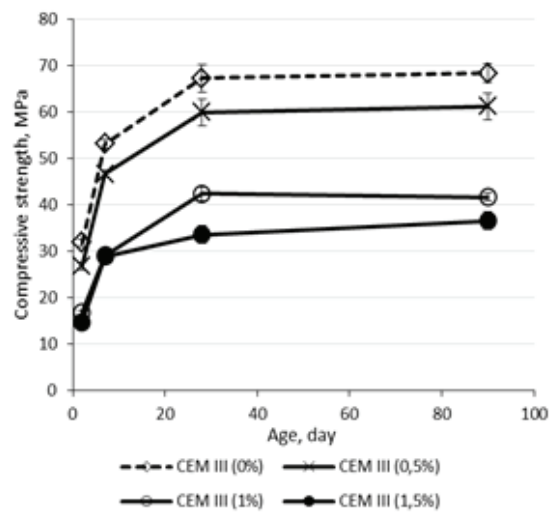

Fig. 2. Development of compressive strength of expansive concrete with cement a) CEM I, b) CEM III with various contents of expansive admixture

The expansive admixture introduced into the concrete mix in the quantity of $0.5 \%$ of the CEM I cement mass did not significantly affect the concrete's compressive strength (Fig. 2a). The obtained compressive strengths of the CEM I samples $(0.5 \%)$ were similar to the strength of samples without admixture. It was only after 2 days of curing that the small amount of expansive admixture caused an approx. $11 \%$ drop in compressive strength. Further increase in the dosage of the expansive admixture resulted in the reduction of the concrete's strength. After 28 days of curing, a decrease in compressive strength by approx. $13 \%$ and $23 \%$ was recorded for samples including admixture in the quantity of 1 and $1.5 \%$ of the CEM I cement mass, respectively. The obtained results correspond to the reduction in the compressive strength class from $\mathrm{C} 50 / 60$ for reference concrete to $\mathrm{C} 35 / 45$ for concrete with expansive admixture in the quantity of $1.5 \%$ of cement's mass. In the case of concrete with the CEM III cement, adding the expansive admixture in the smallest quantity used $(0.5 \%)$ resulted in the reduction of the concrete's compressive strength (Fig. 2b). Further increase in the admixture's quantity featured a reduction in compressive strength. After 28 days of curing, the compressive strength decreased by approx. 11, 37 and as much as $50 \%$ after adding the admixture in the quantity of $0.5,1$ and $1.5 \%$ of cement's mass in comparison to reference samples without admixture. 
Admixtures in the quantity of $1.5 \%$ of the CEM III cement mass caused a reduction in the compressive strength class from $\mathrm{C} 55 / 67$ (samples without the admixture) to $\mathrm{C} 25 / 30$. The expansive admixture reduces the strength of concrete with CEM III substantially more than in the case of concrete with CEM I.

The reduction in the strength of concretes after adding the expansive admixture is in accordance with literature findings [8]. This phenomenon is related to the emission of gaseous hydrogen in the concrete mix, which contributes to the increase in the concrete's porosity. Concrete without admixture featured visible spherical voids with diameters of up to $3 \mathrm{~mm}$. In the case of concretes with expansive admixture in the quantity of 1 and $1.5 \%$ of cement mass, an increased number of voids with a diameter of 1-3 mm, which were deeper than in concrete without admixture, was observed. Furthermore, concretes with expansive admixture featured a large quantity of evenly distributed small pores (Fig. $3)$.

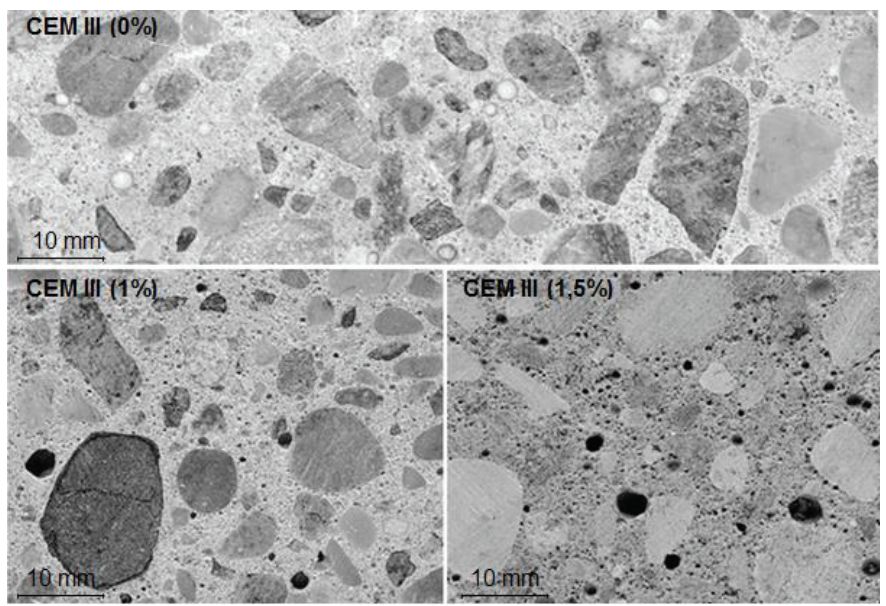

Fig. 3. The influence of expansive admixture on the macrostructure of concrete from CEM III cement. Photo Krzysztof Ziętkowski 
Due to the increased porosity of samples with the expansive admixture a decrease in the concrete's bulk density along with an increase in the content of expansive admixture was observed (Table 6). An exception was the CEM I concrete $(0.5 \%)$, the density of which was similar to the density of CEM I concrete without admixture. The results of the strength testing correlate with the concrete's density. Linear dependency between the concrete's compressive strength and its density was obtained (Fig. 4) with the determination coefficient $R^{2}=0.96$, which indicates a good matching between the test results and the linear dependency.

Table 6. The influence of expansive admixture on the bulk density of concrete

\begin{tabular}{|c|c|c|}
\hline \multirow{2}{*}{$\begin{array}{c}\text { Content of expansive admixture, } \\
\text { \% of cement mass }\end{array}$} & \multicolumn{2}{|c|}{ Density of concrete, $\mathrm{kg} / \mathrm{m}^{3}$} \\
\cline { 2 - 3 } & CEM I & CEM III \\
\hline 0 & $2310 \pm 17$ & $2387 \pm 10$ \\
\hline 0,5 & $2337 \pm 13$ & $2332 \pm 18$ \\
\hline 1 & $2284 \pm 8$ & $2223 \pm 18$ \\
\hline 1,5 & $2221 \pm 14$ & $2148 \pm 12$ \\
\hline
\end{tabular}

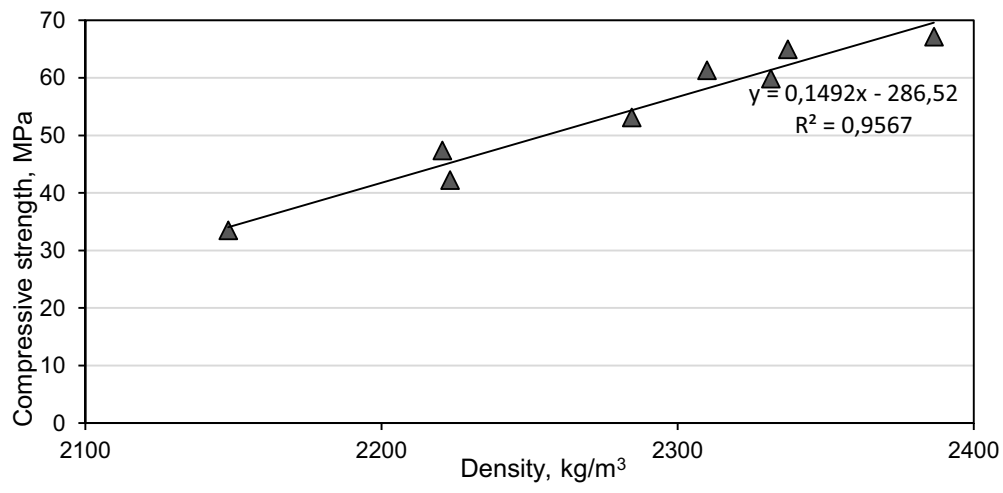

Fig. 4. Dependence of the compressive strength of expansive concrete on bulk density

\section{Evaluation of the admixture's impact on the protective properties of the concrete cover}


The $\mathrm{pH}$ values of aqueous extracts from all concretes were high and amounted to 12.6, which indicates to the lack of the tested expansive admixture's impact on the concrete's $\mathrm{pH}$.

The courses of all steel polarisation curves in aqueous extracts from concrete with CEM III are very similar to one another (Fig. 5) and point to the lack of the admixture's impact on reinforcement corrosion. The obtained polarisation curves demonstrate current plateau in a wide range of potentials, characterised by low anode current values $\left(<10 \mathrm{cA} / \mathrm{m}^{2}\right)$. This suggests the existence of a passive layer on steel with good protective properties.

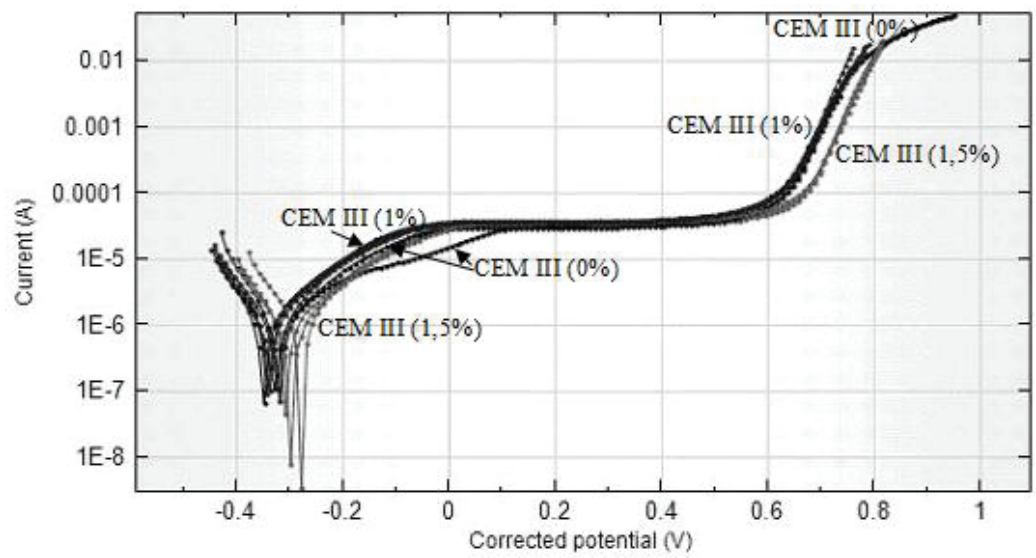

Fig. 5. Steel polarization curves in water extracts from concrete with CEM III with an expansive admixture, after IR drop correction

The obtained corrosion potential $\left(E_{\text {cor }}\right)$, breakdown potential $\left(E_{d}\right)$ passivation current densities $\left(j_{p}\right)$ meet the requirements of the PN-B-01810:1986 standard [9] for steel in a passive state (Table 7). The parameter determining the corrosion rate is the corrosion current density ( $\left.\mathrm{j}_{\text {cor }}\right)$. The $\mathrm{j}_{\text {cor }}$ values designated based on the obtained polarisation curves are low $\left(<0,5 \mu \mathrm{A} / \mathrm{cm}^{2}\right)$ and similar to one another, which indicates a low and similar steel corrosion rate in all of the tested aqueous extracts from concretes and the lack of impact of the used admixture on the corrosion rate of steel in concrete. The obtained values jcor do not exceed the values specified in literature for steel in a passive state [23]. 
Table 7. Parameters of anodic curves of steel polarization in concrete from blast furnace cement with expansive admixture

\begin{tabular}{|c|c|c|c|c|c|}
\hline $\begin{array}{c}\text { Admixture } \\
\text { content, } \%\end{array}$ & $\mathrm{E}_{\mathrm{cor}}, \mathrm{V} / \mathrm{NEK}$ & $\mathrm{E}_{\mathrm{d}}, \mathrm{V} / \mathrm{NEK}$ & $\mathrm{j}_{\mathrm{p}} \mu \mathrm{A} / \mathrm{cm}^{2}$ & $\mathrm{j}_{\mathrm{cor}}, \mu \mathrm{A} / \mathrm{cm}^{2}$ & $\mathrm{R}_{\mathrm{p}}, \mathrm{k} \Omega / \mathrm{cm}^{2}$ \\
\hline 0 & $-0,33 \pm 0,03$ & $0,55 \pm 0,02$ & $9,2 \pm 1,2$ & $0,38 \pm 0,05$ & $84 \pm 10$ \\
\hline 1 & $-0,34 \pm 0,01$ & $0,55 \pm 0,01$ & $9,8 \pm 1,1$ & $0,44 \pm 0,07$ & $73 \pm 9,1$ \\
\hline 1,5 & $-0,30 \pm 0,01$ & $0,62 \pm 0,01$ & $9,3 \pm 0,9$ & $0,37 \pm 0,03$ & $87 \pm 13$ \\
\hline $\begin{array}{c}\text { Requirements } \\
\text { for passive } \\
\text { steel acc. B- } \\
01810: 1986\end{array}$ & $>-0,35$ & $0,45-0,70$ & $<15^{\mathrm{a}}<10^{\mathrm{b}}$ & - & - \\
\hline
\end{tabular}

$\mathrm{a}-$ for ordinary steel, $\mathrm{b}$ - for prestressing steel

\section{Diffusion of chloride ions}

The starting concentration of chloride ions, both in the CEM III $0 \%$ and CEM III $1 \%$ samples amounted to $0.02 \%$. After 31 days of exposure to $\mathrm{NaCl}$ solution, the samples collected from CEM III $1 \%$ showed one and a half higher content of chlorides than samples from CEM III 0\% (Fig. 6), which indicates faster penetration of chloride ions into concrete with $1 \%$ admixture. This is related to the higher porosity of concrete with expansive admixture.

Fig. 6 shows the distribution of chloride content in CEM III $0 \%$ and CEM III 1\% concrete after correction with the starting content of chlorides in concrete and fitting the data to Eq. (2.1). Very good matching in all cases (also in the case without correction with the starting content of chlorides in concrete) was achieved.

Despite a clear difference in the chloride contents in concretes with and without admixture, the chloride ion effective diffusion coefficient in the CEM III concrete with admixture are only slightly higher than the values obtained for the CEM III concrete without admixture (without taking into consideration the correction with the starting chloride content in concrete, $D_{\text {eff }}$ are similar for both concretes) (Table 8). The concentration of chloride ions in the subsurface layer of concrete with admixture is higher than in the case of no admixture. This means that the samples with admixture featured a higher gradient of chloride ion concentrations, which explains the higher chloride ion contents in the CEM III 1\% concrete despite similar $\mathrm{D}_{\text {eff }}$ values. On the other hand, the higher chloride 
concentration in the subsurface layer of CEM III $1 \%$ can result from the better developed surface (larger number of pores) than the CEM III $0 \%$ concrete.

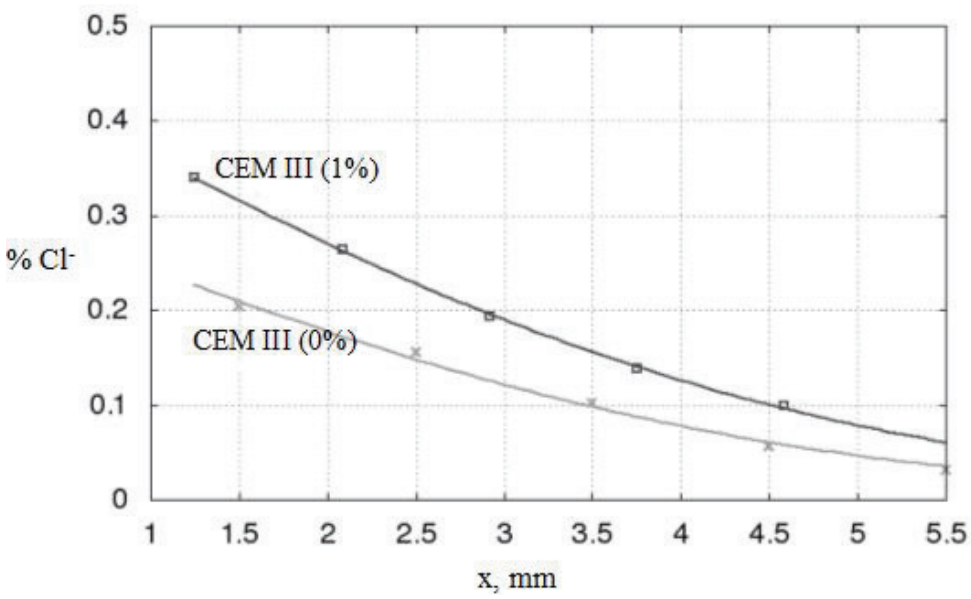

Fig. 6. Dependence of chlorides content in concrete made of cement CEM III containing 0 and $1 \%$ expansive admixtures on the concrete depth (points) fitted to Eq. (2.1) (lines).

Table 8. The effective diffusion coefficients of chlorides in concrete from CEM III with and without expansive admixture after 31 days of chloride penetration

\begin{tabular}{|c|c|c|}
\hline \multirow{2}{*}{} & \multicolumn{2}{|c|}{$D_{\text {eff, }} \mathrm{m}^{2} / \mathrm{s}, 10^{-12}$} \\
\cline { 2 - 3 } & CEM III $0 \%$ & CEM III $1 \%$ \\
\hline $\begin{array}{c}\text { without } \\
\text { correction }\end{array}$ & 2,75 & 2,80 \\
\hline after correction & 2,23 & 2,47 \\
\hline
\end{tabular}




\section{Conclusions}

Based on the conducted testing of the impact of the expansive admixture including aluminium powder, it is possible to formulate the following conclusions:

- When adding the expansive admixture to the concrete mix, it is necessary to take into consideration the possible change in consistency (less liquid) and the related reduction in the mixture's workability. - The technology of preparing the concrete mix with the use of the expansive admixture affects the latter increase in volume. In the case of CEM I, a much better effect was obtained when the expansive admixture was added at the end, i.e. to other already mixed components, instead of dry mixing it with cement, and then added to the previously mixed aggregate. It is necessary to verify the effect of the expansive admixture in time depending on other concrete components on a case-by-case basis. The expansive admixture causes concrete expansion when dosed above $0.5 \%$ of the cement's mass.

- The use of expansive admixture is more effective in concrete with Portland cement both in terms of concrete expansion and the associated concrete strength decrease, which is substantially lower than in concrete with blast furnace cement.

- The use of expansive admixture in the quantity of above $0.5 \%$ of the CEM I cement's mass causes a drop in the concrete's density and reduction in the concrete's compressive strength. After 28 days, the compressive strengths of concretes with the admixture in the quantity of 1 and $1.5 \%$ of the CEM I cement mass were reduced by approx. $13 \%$ and $23 \%$, respectively. The obtained results correspond to the reduction in the concrete class from $\mathrm{C} 50 / 60$ for reference concrete to $\mathrm{C} 35 / 45$ for concrete with expansive admixture in the quantity of $1.5 \%$ of cement mass.

- In the case of using the CEM III cement, the increase in the quantity of expansive admixture causes an increase in porosity and reduction in bulk density of the concrete samples in the entire tested scope of admixture dosages.

- The CEM III concrete's compressive strength is decreasing along with the increase in the quantity of expansive admixture in the concrete's composition. The percentage drop in the concrete's compressive strength in relation to the comparable concrete without the admixture amounts to $11 \%$ (for $0.5 \%$ of expansive admixture), $37 \%$ (for $1 \%$ of expansive admixture) and $50 \%$ (for $1.5 \%$ of 
expansive admixture). After adding admixture in the quantity of $1.5 \%$ of the CEM III cement mass, the concrete class was reduced from C55/67 (samples without the admixture) to $\mathrm{C} 25 / 30$.

- The reduction in the CEM I concrete's compressive strength due to the expansive admixture is smaller than in the case of concrete with blast furnace cement.

- The expansive admixture does not affect the corrosion of reinforcing steel. Steel in aqueous extracts from concrete with CEM III cement including admixture in the quantity of 1 and $1.5 \%$ of the cement's mass was in a passive state.

- Expansive admixture added in the quantity of $1 \%$ of cement mass causes a slight increase in the chloride ions' effective diffusion coefficient in concrete from CEM III cement.

\section{REFERENCES}

1. ASTM C845-96 "Standard Specification for Expansive Hydraulic Cement"

2. A. Bentur, N. Berke, S. Diamond, "Steel Corrosion in Concrete: Fundamentals and civil engineering practice", Modern Concrete Technology, CRC Press, 2014.

3. A. Cheng, R. Huang, J.-K. Wu, Ch.-H. Chen, "Influence of GGBS on durability and corrosion behaviour of reinforced concrete", Materials Chemistry and Physics, 93: 404-411, 2005.

4. M. Król, W. Tur, "Beton ekspansywny", Arkady, Warszawa, 1999.

5. W. Kurdowski, „Chemia cementu i betonu”, Polski Cement, PWN, Kraków, 2010.

6. N. Narayanan, K. Ramamurthy, "Structure and properties of aerated concrete: a review", Cement and Concrete Composites, 22: 321-329, 2000.

7. A. M. Neville, "Właściwości betonu”, Polski Cement, Kraków, 2000.

8. P. Panyakapo, M. Panyakapo, "Reuse of thermosetting plastic waste for lightweight concrete" Waste Management, 28: 1581-1588, 2008.

9. PN-B-01810:1986 „Antykorozyjne zabezpieczenia w budownictwie - Własności ochronne betonu w stosunku do stali zbrojeniowej - Badania elektrochemiczne".

10. PN-EN 197-1:2012: „Cement -- Część 1: Skład, wymagania i kryteria zgodności dotyczące cementów powszechnego użytku".

11. PN-EN 206:2014-04. „Beton: Wymagania, właściwości, produkcja i zgodność”.

12. PN-EN 934-2:2010 „Domieszki do betonu, zaprawy i zaczynu -- Część 2: Domieszki do betonu - Definicje, wymagania, zgodność, oznakowanie i etykietowanie”.

13. PN-EN 934-4:2009 „Domieszki do betonu, zaprawy i zaczynu. Część 4: Domieszki do zaczynów iniekcyjnych do kanałów kablowych. Definicje, wymagania, zgodność, oznakowanie i etykietowanie”.

14. PN-EN 1008:2004 „Woda zarobowa do betonu”.

15. PN-EN 12350-2:2011 „Badania mieszanki betonowej -- Część 2: Badanie konsystencji metodą opadu stożka”

16. PN-EN 12390-1:2001 „Badania betonu - Część 1: Kształt, wymiary i inne wymagania dotyczące próbek do badania i form".

17. PN-EN 12390-2 „Badania betonu - Część 2: Wykonywanie i pielęgnacja próbek do badań wytrzymałościowych".

18. PN-EN 12390-3:2011 „Badania betonu - Część 3: Wytrzymałość na ściskanie próbek do badań”. 
19. PN-EN 12390-4:2001 „Badania betonu - Część 4: Wytrzymałość na ściskanie - Wymagania dla maszyn wytrzymałościowych".

20. PN-EN 12620+A1:2010, Kruszywa do betonu” .

21. P. Trębaczkiewicz, M. Winch, "Spoiwa na bazie cementu ekspansywnego", Górnictwo i Geoinzynieria 3, 441, 2007.

22. F. Wang, Z. Liu, S. Hu, “ Early age volume change of cement asphalt mortar in the presence of aluminum powder", Materials and Structures, 43: 493-498, 2010.

23. G. Wieczorek, "Korozja zbrojenia inicjowana przez chlorki lub karbonatyzację otuliny”,. Dolnośląskie Wydawnictwo Edukacyjne, Wrocław, 2002. 


\section{LIST OF FIGURES AND TABLES:}

Fig. 1. The expansion of the samples after 60 minutes from contact of cement with water Rys. 1. Ekspansja próbek po 60 minutach od kontaktu cementu z wodą

Fig. 2. Development of compressive strength of expansive concrete with cement a) CEM I, b) CEM III with various contents of expansive admixture

Rys. 2. Rozwój wytrzymałości na ściskanie betonu ekspansywnego z cementem a) CEM I, b) CEM III z różną zawartością domieszki ekspansywnej

Fig. 3. The influence of expansive admixture on the macrostructure of concrete from CEM III cement Rys. 3. Wpływ domieszki ekspansywnej na makrostrukturę betonu z cementu CEM III

Fig. 4. Dependence of the compressive strength of expansive concrete on bulk density Rys. 4. Zależność wytrzymałości na ściskanie betonu ekspansywnego od gęstości objętościowej

Fig. 5. Steel polarization curves in water extracts from concrete with CEM III with an expansive admixture, after IR drop correction

Rys. 5. Krzywe polaryzacji stali w wyciągach wodnych z betonu z CEM III z domieszką ekspansywną: 1\%, $1,5 \%$ i bez domieszki po odjęciu spadku IR

Fig. 6. Dependence of chlorides content in concrete made of cement CEM III containing 0 and $1 \%$ expansive admixtures on the concrete depth (points) fitted to Eq. (2.1) (lines)

Rys. 6. Rozkład zawartości chlorków w betonie CEM III 0\%i CEM III 1\%, (punkty) i dopasowanie do równania (1) (linie), po korekcie o wyjściową zawartość chlorków w betonie

Tab. 1. Physicochemical parameters of Portland and blast furnace slag cement acc. manufacturers' data Tab. 1. Parametry fizykochemiczne cementu portlandzkiego i hutniczego wg. danych producentów

Tab. 2. Properties of the admixtures used

Tab. 2. Właściwości użytych domieszek

Tab. 3. Composition of designed concretes

Tab. 3. Składy betonów

Tab. 4. The results of height increase - expansion of concrete specimens

Tab. 4. Wyniki pomiaru przyrostu wysokości-ekspansji próbek betonowych

Tab. 5. The results of the measurement of the consistency of a concrete mix using the clone slump method

Tab. 5. Wyniki pomiaru konsystencji mieszanki betonowej za pomocą metody opadu stożka

Tab. 6. The influence of expansive admixture on the bulk density of concrete

Tab. 6. Wpływ domieszki ekspansywnej na gęstość objętościową betonu

Tab. 7. Parameters of anodic curves of steel polarization in concrete from blast furnace cement with expansive admixture 
Tab. 7. Parametry krzywych anodowych polaryzacji stali w betonie $\mathrm{z}$ cementu hutniczego z domieszką ekspansywną

Tab. 8. The effective diffusion coefficients of chlorides in concrete from CEM III with and without expansive admixture after 31 days of chloride penetration

Tab. 8. Wartości efektywnego współczynnika dyfuzji jonów chlorkowych w betonie z CEM III bez i z domieszką po 31 dniach wnikania chlorków 


\section{ANALIZA WLAŚCIWOŚCI BETONU EKSPANSYWNEGO Z CEMENTEM PORTLANDZKIM I HUTNICZYM}

Słowa kluczowe: domieszka ekspansywna, cement portlandzki, cement hutniczy, beton, wytrzymałość na ściskanie, krzywa polaryzacji stali, dyfuzja chlorków

\section{STRESZCZENIE:}

W pracy przedstawiono wyniki badań właściwości betonów ekspansywnych o w/c $=0,37$ wykonanych z dwóch rodzajów cementu: cementu portlandzkiego CEM I i cementu hutniczego CEM III. Ekspansję betonu wywołano domieszką ekspansywną zawierającą proszek aluminiowy dozowaną w ilości 0,5; 1 i 1,5\% masy cementu. Dotychczas proszek aluminiowy był wykorzystywany w technologii betonu m.in. do napowietrzania betonu, produkcji betonu lekkiego, produkcji betonu komórkowego. Proszek aluminiowy w zasadowym środowisku mieszanki betonowej wchodzi w reakcje, w wyniku których wydziela się gazowy wodór. Pod wpływem ciśnienia wywieranego przez wytwarzający się gaz następuje wzrost objętości mieszanki betonowej. $\mathrm{Z}$ tego względu proszek aluminiowy może być wykorzystany do produkcji betonów ekspansywnych, do efektywnego wypełniania trudnodostępnych miejsc takich jak szczeliny czy ubytki, a także do produkcji betonów o ograniczonym skurczu w celu zapobiegania zarysowaniom.

W pracy przedstawiono wyniki następujących badań: badanie konsystencji mieszanki betonowej metodą opadu stożka, badanie wytrzymałości na ściskanie betonu oraz badania zdolności ochronnych betonu dla stali zbrojeniowej w zakresie badań korozyjnych stali w wyciągach wodnych $\mathrm{z}$ betonów i dyfuzji jonów chlorkowych w betonie. Dodatkowo określono przyrost objętości betonu - ekspansję betonu w czasie do 1 godziny od wymieszania składników mieszanki betonowej. Stwierdzono, że dodając domieszkę ekspansywną do mieszanki betonowej trzeba wziąć pod uwagę możliwą zmianę konsystencji (mniej ciekła) i wiążący się z tym spadek urabialności mieszanki. Ponad to technologia przygotowania mieszanki betonowej, przy użyciu domieszki ekspansywnej, ma wpływ na późniejszy przyrost objętości. W przypadku CEM I znacznie lepszy efekt uzyskano dodając domieszkę ekspansywną na koniec, do wymieszanych już pozostałych składników, zamiast mieszania jej z cementem na sucho, a następnie dodawania do wstępnie wymieszanego kruszywa. Zauważono, że domieszka ekspansywna powoduje ekspansję betonu przy dozowaniu powyżej $0.5 \%$ masy cementu.

Stwierdzono obniżenie wytrzymałości na ściskanie betonu z CEM I po zastosowaniu domieszki ekspansywnej w ilości powyżej $0,5 \%$ masy cementu oraz obniżenie wytrzymałości na ściskanie betonu z CEM III po dodaniu domieszki w całym zakresie stosowanych dozowań. Stosowanie domieszki ekspansywnej jest efektywniejsze w betonie z cementem portlandzkim zarówno jeśli chodzi o ekspansję betonu, jak i towarzyszący jej spadek wytrzymałości betonu, który jest zdecydowanie mniejszy niż w betonie z cementem hutniczym.

Na podstawie pomiarów elektrochemicznych stwierdzono brak wpływu domieszki ekspansywnej na korozję stali zbrojeniowej. Stal zarówno w wyciągu wodnym z betonu bez domieszki jak i z domieszką ekspansywną znajdowała się w stanie pasywnym. Odnotowano nieznaczne zwiększenie efektywnego współczynnika dyfuzji jonów chlorkowych w betonie po zastosowaniu domieszki ekspansywnej. 